\title{
Moral Injury and the Ethics of Educational Injustice
}

\section{Citation}

Levinson, Meira. 2015. "Moral Injury and the Ethics of Educational Injustice." Harvard

Educational Review 85 (2) (June): 203-228. doi:10.17763/0017-8055.85.2.203.

\section{Published Version}

doi:http://dx.doi.org.ezp-prod1.hul.harvard.edu/10.17763/0017-8055.85.2.203

\section{Permanent link}

http://nrs.harvard.edu/urn-3:HUL.InstRepos:17368460

\section{Terms of Use}

This article was downloaded from Harvard University's DASH repository, and is made available under the terms and conditions applicable to Open Access Policy Articles, as set forth at http:// nrs.harvard.edu/urn-3:HUL.InstRepos:dash.current.terms-of-use\#OAP

\section{Share Your Story}

The Harvard community has made this article openly available.

Please share how this access benefits you. Submit a story.

\section{Accessibility}




\section{Moral Injury and the Ethics of Educational Injustice}

\section{Meira Levinson ${ }^{1}$}

\section{Abstract}

This article uses a case study of a student who is on the verge of expulsion for bringing pot to school in order to explore a class of ethical dilemmas in which educators have the obligation to enact justice - to take action that fulfills the demands of justice — but have to do so under conditions in which no just action is possible because of contextual and school-based injustices. Under such circumstances, educators suffer moral injury: the trauma of perpetrating significant moral wrong against others despite one's wholehearted desire and responsibility to do otherwise. Drawing upon Hirschman's classic Exit, Voice, and Loyalty as an analytic heuristic, it is possible to see educators as trying to avoid moral injury in intrinsically unjust contexts by engaging in "loyal" subversion, using their "teacher voice" to protest systemic injustices, or "exiting" the school setting altogether. Each of these approaches, however, is an imperfect option for enacting justice under conditions of pervasive injustice. No approach enables educators adequately to fulfill their obligation to enact justice — and hence, no approach enables them fully to escape moral injury. Although it is educators who suffer the moral injury, it is society that owes them moral repair - most importantly, by restructuring educational and other social systems so as to mitigate injustice. In assuming these obligations, society must also collaborate with experienced educators, who often have insight into how changes to classroom, school, and district practices can cut through what otherwise appear to be intractable normative challenges and hence further mitigate moral injury. At the same time, moral injury will never be fully

\footnotetext{
${ }^{\mathbf{1}}$ For feedback on earlier drafts, I am grateful to interlocutors at Penn State, Harvard's Civic and Moral Education Initiative, Nuffield Political Theory Workshop, Carolina Brito, Kailey Burger, Jacob Fay, Ilana Finefter, Houman Harouni, Jal Mehta, Tom Preston, Julie Reuben, Victoria Theisen-Homer, and Deepa Vasudevan.
} 
eliminated. When one egregious form of systemic injustice is eliminated, previously overlooked injustices may become visible. It is also better that educators recognize the injustices they perpetrate as injustices rather than being unaware of the moral compromises they are forced to make. Case studies of dilemmas of justice may nonetheless enable philosophers, educators, and members of the general public to engage in grounded reflection as a means of achieving phronetic equilibrium, thus further reducing moral injury and enhancing educators' capacities to enact justice in schools.

\section{Article}

In Fall 2013, Jorge was a fifteen year-old, mild-mannered freshman at St. Francis, a small Catholic high school located in a low-income, city neighborhood. ${ }^{2}$ Jorge came to St. Francis with a troubled background. He had been involved with drugs in middle school and had a probation officer due to prior offenses. Ever since his mother's death a few years earlier, he had lived with his aunt and his father, who was in counseling for anger management after admitting to having abused Jorge in the past. Jorge had low reading and math scores, unsurprisingly given his spotty prior academic engagement. On the other hand, Jorge clearly also had an earnest desire to go to college. He was smart, and seemed to be committed to working hard. His aunt had fiercely advocated for Jorge's acceptance into St. Francis, which was established to serve

\footnotetext{
2 Jorge's case was researched and originally drafted by Carolina Brito, a student in my research project on Justice in Schools (http://justiceinschools.org). I am grateful to her for allowing me to use the case here and elsewhere. The names in this case are pseudonyms; all events, statistics, and quotations, however, are utterly accurate. In line with this commitment to authenticity, Carolina and I have selected pseudonyms that signal the student's Latino and admission director's Spanish self-identities. The priest identifies as an immigrant from Southern Italy. The other school personnel named in this article identify as white. Although race and ethnicity are not a primary focus of this article, it would be empirically and normatively inappropriate to obscure the ethnoracial dynamics potentially at work in this case, which we invite others to address in more detail. One purpose in offering such a detailed account of this case, in fact, is to enable others to analyze the case through alternative lenses and for different ends than I analyze the case here.
} 
low-income and working-class students very much like Jorge. St. Francis accepted him, therefore, knowing that there might be some bumps along the way.

Jorge's first misstep came quickly, just a month into his freshman year, when he was arrested outside of school for breaking and entering into a car. St. Francis agreed to oversee his required community service hours, as requested by his probation officer (P.O.). As Dean of Students Deborah Dunn explained it, however, his P.O. also made clear that "if anything else happened, whether it was a behavioral issue where he got suspended, or whether it was an issue with a teacher, or anything like that, ... we could not unfortunately keep him as a student here." Following the theft, Jorge revealed to several staff and faculty members that he struggled with drug addiction and regularly smoked marijuana with classmates after school. In response, the school called the family in for an intervention — a meeting that brought together school administrators, Jorge and his family, and support staff to craft a plan for how to help Jorge become drug-free. St. Francis also hosted one in-school counseling session for Jorge, and referred him to outside counseling for further support. Jorge and his family never followed up on that referral, however, and St. Francis didn't follow up further with him.

A few weeks later, in October, Jorge was sitting in science class with his closed backpack next to him. It was reeking: the smell of marijuana emanating from it was unmistakable, and impossible to ignore. Mr. Brown, his science teacher, asked him to step out into the hall for a conversation. Mr. Brown asked Jorge what was in his backpack, and Jorge “didn’t even protest. Just dished it over." At that, Mr. Brown took the bag of marijuana to Ms. Dunn's office and reported what had transpired.

Ms. Dunn immediately summoned Jorge to her office and explained to him the severity of his offense. Jorge was distraught about getting into trouble again so soon. In particular, he 
was upset about letting his father and aunt down. He readily admitted to wanting to smoke with a friend after school, but claimed no intent to sell or distribute. He was thunderstruck when Ms. Dunn listed the range of consequences he faced, including expulsion.

Jorge may have been surprised by the potential consequences not only because of the relatively lenient treatment he had received following his breaking and entering charge, but also because other drug and even weapons incidents at the school had not resulted in expulsion. The previous spring, for example, three seniors had brought alcohol and marijuana on a school trip to Washington, D.C. They were punished via out-of-school suspension, community service hours, and exclusion from graduation ceremonies. But they were not expelled; they received their diplomas over the summer. A student distributing marijuana-laced brownies at another senior retreat was suspended for three weeks and then allowed to return to school. On the other hand, the same week as Jorge's incident, a sophomore was found with several dime bags in his shoes and his locker. Because the intent to distribute and sell was clear, the student was asked to leave. Although Ms. Dunn reasoned carefully about each case, she did not discuss her reasons publicly, out of respect for students' privacy. Faculty and students alike were therefore perplexed by the unexplained discrepancies in punishment among the various cases.

This individualization was a feature of St. Francis' discretionary discipline system known as Positive Behavior Intervention and Supports (PBIS). ${ }^{3}$ Thanks to PBIS, St. Francis eliminated detentions and radically reduced the number of suspensions, while increasing individualization of punishments. PBIS encourages faculty and staff to identify reasons for students' recurring behaviors, determine what functions and useful purpose these behaviors serve in students' lives, and identify how they are being reinforced in their environments. A counselor or dean is then

\footnotetext{
${ }^{3}$ See https://www.pbis.org/ for more information about the PBIS approach.
} 
responsible for proposing another possible outcome or offering another, more pro-social, path to achieve the desired goal. As Ms. Dunn explained it a month after Jorge's case:

I think for the most part we look at the individual first....We try to be consistent, but we definitely look at the individual situation. We do pair that with the policies and the procedures. We obviously want to keep students in school as much as we possibly can. Discipline is always punitive and it's always 'you did something wrong, here's your consequence, here's your punishment.' And we're trying so hard to get away from that. We're trying to work with the students. We're trying to correct their behavior. This system, although effective at reducing disciplinary incidents, suspensions, and expulsions, also proved labor and time intensive. It required significant buy-in and work from both students and adults. Moreover, faculty found it nebulous as to when sufficient interventions had been performed, and when behavior could be changed only through punitive consequences.

After hearing Jorge's account, the administration had to decide what to do. Most immediately, the school had to decide whether to inform Jorge's probation officer about what had occurred — a step that would most likely lead to Jorge's removal from St. Francis. Admissions Director Hector Rodriguez strongly opposed informing the P.O. He argued, "Giving Jorge more time to mature in a safe-space would give him a chance to turn around. We shouldn't use Jorge to set an example for the other freshmen. We should...consider what we could do for him." Mr. Rodriguez also emphasized that if Jorge was expelled, his likely new school would be one of the worst high schools in the city, a chronically underperforming "drop-out factory." The data all suggested that if Jorge was forced to leave St. Francis, he faced much higher chances of criminal recidivism, violence, socio-emotional distress, isolation, and exacerbation of the factors likely causing him to retreat to drugs. 
On the other hand, other faculty pointed out many good reasons to report the incident to Jorge's P.O. First and foremost, failure to report would communicate to Jorge that his behavior was inconsequential or outside of the purview of the law. It would also place the school in the position of effectively covering up for student criminal activity. Other students might interpret the school's leniency toward Jorge as carte blanche for their own drug-related or other illegal activity, inside and outside school. The school could end up weakening students' respect for the rule of law, simply to protect Jorge's individual socio-emotional interests. Furthermore, there were practical options that could serve as a middle ground between outright protection and outright expulsion. Jorge could be listed merely as transferring to a new school, not as being expelled from St. Francis. This would enable him potentially to return to St. Francis the following year, and to start his new school with a clean slate. Moreover, Jorge would continue his mandated community service hours in the building, and seek counseling at St. Francis or through the school's outside contacts, even though he would not be enrolled as a student. It was unlikely that Jorge or his guardians would take that initiative, but it remained a formal option.

These were the questions facing Ms. Dunn and the St. Francis administration. Should they hide the incident from Jorge's probation officer and deal with the situation as a school—unbeholden to the law? Should they attempt to negotiate with his P.O. - not withholding the truth, but offering alternatives to removing him from St. Francis? Should they report the incident and hope that Jorge developed greater personal responsibility at his new school? Should they expel him directly themselves? Did the complications that arise in Jorge's case suggest broader flaws in the PBIS system that they should address? What considerations should be strongest in arbitrating Jorge's treatment? 
In this article, I explore some of the challenging moral choices built into this particular case. My more general purpose, however, is to illuminate this general class of ethical dilemmas in education, which have been profoundly neglected by both philosophers and teacher educators despite their ubiquity in many schools and districts. I start by arguing that, as in the case of Jorge and St. Francis, educators have the obligation to enact justice, but they often have to take action under conditions in which no just action is possible. By educators, I mean teachers, aides, administrators, guidance counselors, school nurses, support staff, after-school coordinators, and others who work in schools and have a direct or indirect impact on students' education. Under such circumstances, where just action is both obligatory and impossible, I argue that educators suffer moral injury: the trauma of perpetrating significant moral wrong against others despite one's wholehearted desire and responsibility to do otherwise.

By claiming that just action may simultaneously be obligatory and impossible, I appear to be ignoring the fundamental ethical premise that "ought implies can" (Kant, 1999): in other words, that people can be held morally responsible only for what it is possible for them to do, and that correlatively they cannot be held morally responsible for doing (or failing to do) the impossible. One way that philosophers have tried to maintain this premise, while also acknowledging that unavoidable action that infringes others' rights is regrettable, is to designate such action as having "moral residue" (Thomson, 1990). Such actions are not mere "residuals," however, just as civilians killed during war are not mere "collateral damage." I reject the language of "moral residue" for the same reasons that I adopt the language of "moral injury": in order to emphasize that moral wrongs are being committed in an on-going fashion, and also therefore to push for the identification of an agent that can be held morally responsible for remediating these circumstances under which individuals are forced to take action that wrongs 
others. By pointing out that educators are assuming moral responsibilities that are nonetheless impossible for them to fulfill, I hope to lay the groundwork for the argument in the final section of this paper that society has a collective ethical responsibility to make it possible for educators to act justly.

I first examine three modes through which educators attempt to avoid moral injury in responding to dilemmas in which they are obliged to enact justice in intrinsically unjust contexts. Borrowing from Albert Hirschman's classic Exit, Voice, and Loyalty (Hirschman, 1970) as a heuristic for analysis, ${ }^{4}$ I suggest that educators usually stay "loyal" to their schools, or at least to their students, muddling along and doing the best they can. Loyal muddling doesn't imply strict compliance; rather, it often includes quiet acts of subversion, even proto-civil disobedience, in order to remediate specific wrongs. If Ms. Dunn decided to keep Jorge at St. Francis and hence to keep Jorge's probation officer in the dark, for instance, she would fall in this category. However, while loyal subversion may remediate individual instances of injustice, I argue that it also maintains and even reinforces the status quo. Loyal educators hence become complicit in, even collaborators with, unjust systems.

In response, some educators - and whole schools — eventually exit the system. Teachers and administrators find jobs in schools or districts that do not confront them with repeating cascades of unjust options, or in the extreme, they leave the profession altogether. Schools exit

\footnotetext{
${ }^{4}$ I emphasize my use of Hirschman's work as an analytic heuristic because I am drawing upon the conceptual framework of exit, voice, and loyalty for my own purposes, rather than applying the organizational theory underlying it. It does, however, have some empirical confirmation in the ethics of teaching literature. Elizabeth Campbell's research into teachers' responses to moral dilemmas, for example, echoes the loyalty and voice components of his framework. She finds that teachers choose "to voice moral opposition openly at some personal risk, to 'suspend morality' and quietly subvert the expectation in order to be able to 'live with' oneself yet avoid trouble, or to accept the objectionable and live with the guilt of doing nothing to address that which one feels is morally wrong" (Campbell, 2008, p. 368). Campbell's framework, however, leaves out exit, which as I show below (and as Doris Santoro's recent work shows in greater detail (Santoro, 2014)) is an increasingly visible choice that teachers make in the face of moral injury.
} 
by sundering relationships with particularly challenging children and communities. If St. Francis decided no longer to admit students who have high aspirations but a history of criminal and drug involvement, it would exit by refusing to enter into an educational relationship with other children like Jorge. Some charter schools may be characterized similarly, as they counsel challenging students out and refuse to backfill empty spaces. While exit may protect educators' or schools' personal integrity, however, it doesn't actually address individual or systemic injustice. Jorge doesn't disappear; he just becomes someone else's problem. Individual exit is therefore not a normatively justifiable approach at scale. ${ }^{5}$

Educators' third option is to exercise voice. As I discuss below, some teachers and principals have recently been exercising voice in intriguing ways against high-stakes standardized testing and other features of contemporary education reform. Speaking out—and civic action more broadly — is the most justifiable way to effect change with regard especially to systemic injustice. But at the same time, there are a number of instances in which "using one's teacher voice" is ineffective, untenable, or even inappropriate. St. Francis, Ms. Dunn, and Jorge are pseudonyms, for instance, precisely because it would be inappropriate for Jorge's situation in particular to be made public. Furthermore, it's not clear exactly what St. Francis educators, parents, and students would speak up about. Jorge's and St. Francis' own situations may express a cascade of injustices all of which deserve attention — but what would one publicly protest or advocate at the moment Jorge opened up his reeking backpack and pulled out the bag of marijuana?

\footnotetext{
${ }^{5}$ If all teachers and administrators exited simultaneously — through a coordinated strike or other work action — then it's possible that would force political change to address some of the underlying systemic injustices. This is premised, however, on educators' returning to the classroom once their demands (for additional resources, coordinated social services, etc.) were met; hence, I would classify it as an example of voice rather than exit. I am grateful to Houman Harouni for conversations about this, even though (perhaps especially though!) we continue to have very different views on the matter.
} 
Loyalty, exit, and voice all provide imperfect, partial options for educators who seek to enact justice under conditions of pervasive injustice. No approach enables them adequately to fulfill their obligation to enact justice, nor hence to protect themselves fully from the moral injury that results when they knowingly perpetrate significant moral wrongs against others despite desiring to do otherwise. I conclude, therefore, by discussing not educators' obligations toward students, but society's obligations toward educators given the morally untenable position in which they are placed. Educators rightly feel morally compromised when they enact injustice rather than justice, but it is society that owes them moral repair-most importantly, by restructuring educational and other social systems so as to mitigate injustice. At the same time, moral injury will never be fully eliminated, nor should it be, as it is generated by an appropriately progressive moral engagement. When one egregious form of systemic injustice is eliminated, previously overlooked injustices may become visible. This brings me full circle back to Jorge's case in particular, and to the potential of normative case studies (Thatcher, 2006) that raise dilemmas of educational justice more generally, as one tool through which we might be able to identify, acknowledge, and ultimately mitigate such moral injury.

\section{Educators' Responsibilities to Enact Justice}

Let us start with the claim that educators have an obligation to enact justice. This may seem like a totally self-evident proposition — but it is not one that either political theorists or policy makers tend to embrace. For their part, contemporary political theorists tend to treat justice as a virtue of social systems or institutions, not of individual actors. John Rawls (1971), perhaps the most celebrated political theorist of the past century, characterized justice as built into the "basic structure" of an ideal society. People who live within such an ideal society will themselves be inspired to maintain just institutions, and also have a "natural duty" to "support 
and to comply with just institutions" (Rawls, 1971, p. 99). But Rawls did not believe that justice was a feature of individuals' interpersonal relationships; nor did he discuss schools as part of the basic structure in which justice must prevail. Following his lead, political theorists interested in education have tended to focus on systemic and institutional justice at the highest levels of policy, rather than on educators' obligations to enact justice in particular classrooms, schools, or districts (see, e.g., Allen \& Reich, 2013; Brighouse, 2000; Brighouse \& Unterhalter, 2010; Reich, 2002; Wolfe, 2003). ${ }^{6}$

Contemporary education reformers with policy-making power are also remarkably silent about educators' responsibilities to enact justice, especially at the micro, day-to-day level. As with the political theorists, reformers readily talk about justice with respect to broad institutional aims and initiatives: universal standardized testing, charter autonomies, school funding, or school closures. They also often characterize the overall aims of education reform in powerful moral terms related to equity, civil rights, and so forth. But they provide no evidence or argumentation to support their sweeping moral claims. Furthermore, contemporary elite discourse around teacher practices focuses almost entirely on instructional capacity, mastery of specific teacher "moves," and the like. Similarly, discourse around administrative development tends to focus on management, team building, setting strategy, goal- and data-driven decision-making, and other technical aspects of administrative and policy practice. So long as teachers and administrators engage in "urgent," data-driven instruction and "effective school leadership," their ethical responsibilities are thought to have been satisfied. But this is too simple.

\footnotetext{
${ }^{6}$ (Jencks, 1988) is one notable exception to this pattern, although his analysis is so removed from the particularities of classroom practice and knowledge - in particular, from practical pedagogical knowledge about how to meet diverse students' needs simultaneously — that I fear it harms as much as it helps advance insight into teachers' obligations to enact justice.
} 
By contrast, there is a lively discussion among philosophers of education about educators' moral responsibilities. Such books as Teaching as a Moral Craft (Tom, 1984), The Moral Dimensions of Teaching (Goodlad, Soder, \& Sirotnik, 1990), Professionalism and Ethics in Teaching (Carr, 2000), The Ethical Teacher (Campbell, 2003), Creating the Ethical School (Zubay \& Soltis, 2005), The Ethics of Teaching (Strike \& Soltis, 2009), The Moral Work of Teaching and Teacher Education (Sanger \& Osguthorpe, 2013), and Caring: A Relational Approach to Ethics and Moral Education (Noddings, 2013) all draw readers' attention to educators' roles as moral agents. A very useful literature review by Elizabeth Campbell further documents educational philosophers' recent attention to the "moral essence of teaching and ethical professionalism" (Campbell, 2008, p. 358). These works provide a welcome counterpoint to the amoral, technocratic focus promoted by policy makers and education reformers - or to their bold claims about policies' promotion of social justice without any normative foundationand to the solely systemic and institutional focus of political theorists who write about justice in school policy. This literature tends not, however, to focus on justice as such. It also often focuses on ethical dilemmas that arise when there's a "bad apple:" a colleague who is showing movies in class rather than teaching, or an administrator who cares more about maintaining the school's winning football season than about addressing the quarterback's choice to plagiarize a paper.

As I discuss further below, however, educators must exercise judgments about justice on a regular basis simply in the normal context of teaching and learning. Although cases like Jorge hopefully do not arise every day, more prosaic discipline challenges do. Individual kids with needs that are not being met act out. They disrupt other students' learning and create frustrating, scary, or even unsafe environments for other children. If left unchecked, they may even pull susceptible peers down the wrong path. What should be done? Educators wrestle daily with 
how to deal with such cases. Educators also wrestle with—really, beat themselves up overother everyday dilemmas of justice. What should be done about a student who has failed to meet a number of the benchmarks for promotion to the next grade, but who has worked hard all year and will predictably drop out if she's held back ${ }^{7}$ How should a teacher respond to a student who wants to focus his citizenship project on the immorality of same-sex marriage, when she knows that there are closeted students in the class who are already socially marginalized and at risk of self-harm? ${ }^{8}$ When he sits down to do his lesson plans late at night, after spending three unanticipated hours tending to his sick toddler, should a teacher concentrate on planning his AP American Literature class, full of working-class students for whom college credit will be a tangible boon? On his Sheltered English Immersion class, serving mostly low-income, new immigrants? Or perhaps his drama elective, since the regional competition is only days away? These are pragmatic questions, but they are also intrinsically questions of justice, about who is owed what and why, and educators struggle with them constantly.

They are right to struggle, because educators should enact justice. Public school educators are agents of the state, and as such are the mediators through which the state realizes its responsibility for enacting justice. As Michael Lipsky put it in his famous study of "streetlevel bureaucrats" like social workers, police officers, and teachers, "Citizens directly experience government through them, and their actions are the policies provided by government in important respects" (Lipsky, 2010, pp. xix-xx). Second, whether public or private, schools are agents of justice and injustice. Although Rawls didn't treat them as part of the "basic structure," he should have; it is impossible to achieve a just society without just schools. Schools distribute other primary goods and capabilities such as knowledge, skills, and habits of mind that enable

\footnotetext{
${ }^{7}$ See http://justiceinschools.org for a narrative version of this case.

${ }^{8}$ I discuss the civic implications of this case in (Levinson, 2012, pp. 201-206).
} 
students to gain employment, access additional educational opportunities, and participate as fully empowered citizens. ${ }^{9}$ Third, educators have power over their students. They stand in hierarchical relationship to their students, and have the power to distribute or restrict both goods and punishments. They hence have agency as facilitators of both distributive and retributive justice. Fourth, schools are places in which students learn about justice and learn to enact justice (or injustice) themselves, regardless of whether schools intend to or not. So not only do they both distribute and impose justice, but they also teach justice. Finally, educators should enact justice because we should all enact justice, all other things being equal. Justice is not always the highest value, especially in interpersonal relationships. But in the absence of trumping conflicting values, justice is a value that we all should attempt to realize in our daily lives.

\section{Enacting Justice in Unjust Contexts}

Nonetheless, educators often find themselves in situations in which there is no just action open to them, but they still have to act. One reason for this is the impact of contextual injustices: historical and/or present-day injustices beyond the school. Examples include poverty, trauma, lack of health care, and racial and economic segregation thanks to redlining. A second source of the problem is on-going school-based injustices: lack of resources, training, and professional supports for educators, unjust rules and regulations, or inappropriate school policies. Examples here are somewhat more contested, but might include class loads of 150 students and 4 preps, zero tolerance discipline policies, hiring practices that assign new teachers to the most challenging classrooms in the most challenging schools without a mentor, and assessments that have high-stakes consequences for young children.

\footnotetext{
${ }^{9}$ As I hope is obvious, just schools matter whether one is a Rawlsian, attached to primary goods (Rawls, 1971, 1993), or an advocate of Nussbaum and Sen's capability approach (Nussbaum, 2000; Sen, 1993).
} 
We can see both sources of injustice in Jorge's case. He came into St. Francis having suffered many contextual injustices: poverty, neglect by an overtaxed social welfare system, emotional and possibly physical abuse. He also suffered various school-based injustices—not because of lack of care on the school's part, but that nonetheless made it a challenge for the school to meet Jorge's needs. These included lack of on-site school counselors, a discipline policy that was somewhat obscure to both students and teachers, and an over-stretched faculty who were trying to serve many students like Jorge. I believe that his case poses a real dilemma of justice, one in which there may be better and worse answers, but no fully just ones. It was clearly in Jorge's interest to stay at St. Francis. It is a small, academically rigorous, and caring school. He had developed trusting relationships with a number of adults in the building, as he demonstrated by talking with them about his struggles with drugs, and by so readily and unquestioningly pulling the bag of pot out of his backpack when his science teacher questioned him. His aunt and father were committed to the school, and the school committed itself to Jorge through a remarkably trying first couple of months. The high school that Jorge would attend if he was expelled had a five-year graduation rate of $65 \%-59 \%$ for Hispanic boys such as Jorge. It had a history of disorder, violence, and generalized hopelessness. It was not a school that many parents affirmatively choose for their child.

On the other hand, Jorge's remaining at St. Francis could cause real harms to other students. All the kids in Jorge's science class knew he brought marijuana to school; it was impossible to miss the smell. Nor was that knowledge restricted to his science classmates; by the end of the day, the whole school knew that Jorge had handed Mr. Brown the huge bag of pot that was now perfuming Ms. Dunn's office. Most St. Francis students were struggling to overcome significant contextual injustices themselves. Since the school only admits students who are low 
or moderate-income, about $85 \%$ of St. Francis' students on average are eligible for free or reduced-price lunch, meaning that their families are within $185 \%$ of the poverty line. $97 \%$ are students of color. 100\% of St. Francis graduates have been accepted to college each of the past five years (2010-2014), with $90 \%$ immediately matriculating. Most will be the first in their families to attend, let alone graduate from, college. These are incredibly impressive outcomes, but they don't come easily, and they aren't compatible with an "anything goes" school cultureor even the perception of such a culture among students. How could "saving" Jorge- -yet again - measure against the school's obligations to all of its other students?

Is it even appropriate for the faculty to think in terms of "saving" a child? St. Francis' own priest questioned this idea, suggesting that St. Francis' purpose was to educate, not to save. Even more pointedly, he argued that “mercy doesn't come without justice.” St. Francis should hold Jorge to account now by reporting and expelling him so it becomes possible later to welcome him back into the fold. "I am trying to actually foster that potential and I'm trying to allow [him] to actually grow." From this perspective, not even Jorge benefits from leniency on the school's part, because Jorge himself needs to confront the consequences of his actions before he can experience "redemption." While somewhat more skeptical about the positive impact expulsion is likely to have on Jorge's life, other faculty agreed that "we're not here to save anyone."

Finally, we must take account of Jorge's court involvement and the school's overall relationship with public safety and social service officials. Even if it is legal for St. Francis not to report Jorge's marijuana possession to his probation officer, it is questionable whether students will be well-served in the long run by a school that is uncooperative with the state's juvenile support system. 


\section{A Case (Study) for the Phronetic Method}

I don't have an “answer” about what Ms. Dunn, or the St. Francis faculty as a whole, should do in Jorge's case. I've spent time working through it, however, for two reasons. First, I think it's important to see how school-based and contextual injustices can add up to create “wicked problems" (Rittel \& Webber, 1973) that essentially stymie just solutions no matter which way one turns. These set the stage for educators' experience of moral injury, which I discuss in more detail in the final section of this article.

Second, Jorge's case helps to illuminate some crucial general features of ethical reasoning in non-ideal contexts. Most importantly, it demonstrates the usefulness of taking a phronetic approach: a mode of reasoning through ethical challenges that takes context and specifics seriously, that works up from the non-ideal problem as well as down from ideal theory in order to develop practical wisdom. Aristotle first argued for phronesis in Book VI of his Nicomachean Ethics, explaining that ethical action "is not concerned with universals only. It must also take cognizance of particulars, because it is concerned with conduct, and conduct has its sphere in particular circumstances" (quoted in Flyvbjerg, 2001, p. 70). Within education, Paolo Freire (Freire, 2000 [1970]) takes a very similar methodological stance in his advocacy of praxis: a reflective iteration between theory and practice in order to illuminate both. This necessity of reflective iteration is also why attention to a specific case, rather than discussion of a more general problem, may be especially powerful in reasoning about justice in non-ideal contexts. The preceding discussion has, I hope, demonstrated how the process of discussing a case can help interlocutors identify a pluralistic set of values, ethical stances, and perspectives that are contextually grounded, but also capable of expanding beyond the specific case itself. Bent Flyvbjerg argues in favor of case studies for this reason in his spirited justification of 
"phronetic social science" (Flyvbjerg, 2001), pointing out that "context-dependent knowledge and experience is at the very heart of expert activity" (Flyvbjerg, 2001, p. 71).

The need to help educators develop their capacities to take ethical action- to enact justice, not just to discuss it—also explains why "ideal theory" that develops "a conception of a fully just society" (Rawls, 1971, p. 8) is an insufficient guide for reasoning about non-ideal contexts. This is in part because such theories often are developed to address a different level of decision-making and action than the agent is confronting. For example, some utilitarians argue that maximal utility is best achieved by individual actors making rights-driven decisions that take no direct account of utility at all. Or, a theory may be developed in one way to govern interpersonal interactions, and in another to govern institutional policy formation, but fail to address circumstances — as in Jorge's case - where institutional policy is essentially (re)made and (de)legitimized through community members' interpretations of an interpersonal act (e.g. Ms. Dunn's treatment of Jorge). Furthermore, ideal moral theories tend to assume such characteristics as universal compliance and absence of contextual injustices such as racism. (See (Mills, 2005) for a scathing critique of moral and political theories built on such counter-factual assumptions.) They aren't designed to apply directly, without modification, to the decidedly nonideal circumstances of the contemporary world. ${ }^{10}$

It is also the case that top-down applications of monological ethical theories are incompatible with many human beings' moral psychology. People make decisions in contexts rather than vacuums, embedded in webs of relationships, sensitive (perhaps overly so) to particularities and nuances, adopting roles and perspectives that are situational rather than

\footnotetext{
${ }^{10}$ This disconnect is especially obvious in the educational context, where non-compliance is evident not only in the widespread contextual and school-based injustices with which many educators and students contend, but also in the fact that education involves children, who are by nature not always rational or compliant.
} 
universal. This doesn't mean operating in a merely subjectivist nor a radically particularist frame. Values such as equality, fairness, liberty, integrity, mutual respect, and human welfare must come into play. So must considerations of rights, duties, and consequences. But nonetheless, the reasoning about them flows as much from contextual knowledge and pluralistic reflections on the problem as from references to ideal theories. In other words, human beingsincluding both theorists and educators - are engaged in a process of grounded reflection with the intent to reach a phronetic equilibrium (Levinson, 2014).

\section{Loyal Subversion, or the Art of Muddling Along}

Quite possibly, this full-throated defense of pragmatic ethical pluralism in educational contexts is totally unnecessary, since it merely describes in academic terms what many educators do as a matter of course: namely, muddle along the best they can, trying to make the most just decisions in the moment, maintaining their loyalty to their students, school, and profession, and subverting the policies, institutions, or structures that worsen injustice and subject themselves to moral injury if and when they think they can get away with it. In this respect, educators who care about justice assert similar autonomy to the peasants James Scott describes in Weapons of the Weak (Scott, 1985), or the street-level bureaucrats described by Lipsky. They attempt to use what authority they have to "respond generously to people in need despite rules to the contrary" (Lipsky, 2010, pp. 229-230), joining "the moral underground" in doing so (Dodson, 2011). Their subversion is an exercise in proto-civil disobedience, precisely because it remains hidden within the cloak of authentic loyalty.

As a result, even if they manage to subvert policies or injustices in particular cases-even if Ms. Dunn figures out how to "save" Jorge without tipping off his probation officer-educators who engage in quiet subversion contribute to maintaining the overall status quo, doing little to 
create a systemically more just approach or set of institutions. Again Lipsky provides compelling, albeit depressing, insight:

Some street-level bureaucrats drop out or burn out relatively early in their careers. Those who stay on...often grow in the jobs and perfect treatment and client-processing techniques that provide an acceptable balance between public aspirations for the work and the coping requirements of the job. These adjustments of work habits and attitudes may reflect lower expectations for themselves, their clients, and the potential of public policy. Ultimately, these adjustments permit acceptance of the view that clients receive the best that can be provided under prevailing circumstances. Street-level bureaucrats often spend their work lives in these corrupted worlds of service. (Lipsky, 2010, p. xv)

In this respect, acquiescence may be tantamount to complicity with injustice: one becomes if not a responsible collaborator, at least a silent complicitor (Thompson, 1980).

Complicity may admittedly be justifiable, even morally obligatory, if the alternative would result in worse social consequences-if, for example, less-scrupulous others will simply take their place. Dennis Thompson warns, "We are right to be suspicious of such pleas; the heady mixture of exercising power while believing oneself to be doing good can easily forestall a sober assessment of the consequences of alternative courses of action. Still, the plea is sometimes surely acceptable" (Thompson, 1980, p. 910). However, silent complicity, and even (or perhaps especially) loyal subversion, can end up exacerbating injustice significantly. If Ms. Dunn fails to report Jorge to his probation officer, for example, then she perpetuates the sham that Jorge's needs are being met. Neither his P.O. nor other providers of out-of-school social services learn, or are held accountable for, the fact that Jorge is not turning his life around with the resources at hand. This doesn't just harm Jorge. It also potentially harms all other court-involved children 
who need - but will continue not to be provided — a more comprehensive suite of services. Without evidence of failure, there's no cause to change.

Similar problems arise in the wake of standardized test cheating scandals. There is evidence that at least some educators who cheat do so because they care deeply about their students. Outraged by the negative effects of high-stakes standardized tests whose validity and soundness they question, and committed to helping their students access the life-changing goods of promotion, graduation, college, and career, educators take various steps to ease the burden, from bending the rules to outright falsification of student data. In her searing account of cheating at Parks Middle School in Atlanta, for example, New Yorker writer Rachel Aviv found that "most teachers thought they were committing a victimless crime. 'They didn't see the value in the test, so they didn't see that they were devaluing the kids by cheating," a lawyer explains to her. Aviv concludes that "those who cheated at Parks were never convinced of the importance of the tests; they viewed the cheating as a door they had to pass through in order to focus on issues that seemed more relevant to their students' lives" (Aviv, 2014).

This kind of quiet subversion, however, sets students up for even worse outcomes in the long run. One of the most tragic fallouts from the Atlanta cheating scandal, for example, was the discovery that Atlanta Public School students lost compensatory reading programs and other supplemental services because they were doing too well. Also, students who passed from a teacher in one grade who did cheat, to a teacher in the next grade who didn't, appeared to lose academic ground and hence failed to make "adequate yearly progress," or AYP. This led to corrective actions and teacher and principal firings that upended school stability — as well as to further cheating - and again worsened students' opportunities. No matter how unjust some of 
these standardized tests might be, therefore, quiet subversion that is "stuck at the classroom door" (Picower, 2012) may well make the injustice far worse.

\section{Finding One's Teacher Voice}

Given the costs of silence, subversive loyalty should probably give way to voice: to some form of public critique. As experienced professionals, educators have specialized knowledge about the challenges, opportunities, and injustices in education that can inform public debate. Their voices are authentic: they know whereof they speak. By exercising voice, they can recover some of their personal moral integrity, as well as perhaps restore their professional integrity: what Doris Santoro, following Thomas Green, calls "craft conscience," or "the integrity of the individual qua practitioner and the integrity of the profession itself' (Santoro, 2014). Educators' day-to-day work may remain tainted by complicity, but by drawing public attention to the injustices that they and their students live through, educators can foster a critical stance toward present-day practice that challenges rather than maintains the status quo. Educators' exercise of public voice is also a fabulous example for students; it is important for students to see adults they know and respect speaking out against social injustices. Furthermore, students don't need to remain mere spectators themselves. Educators can work with students to help them exercise their own civic voices - thus simultaneously combatting extant injustices and inducting the next generation into a tradition of empowered civic participation (Apple \& Beane, 2007; Levinson, 2012; Westheimer \& Kahne, 2002).

There are some fascinating and even inspiring contemporary examples of educators working collectively to exercise their voices, in particular against high-stakes standardized testing. One trio of teachers in New York City has dubbed themselves "Teachers of Conscience," and issued a position paper explaining: 
As an act of conscience, we are declining the role of test administrators for the 2014 New York State Common Core Tests. We are acting in solidarity with countless public school teachers who have paved their own paths of resistance and spoken truthfully about the decay of their profession under market-based reforms. These acts of conscience have been necessary because we are accountable to the children we teach and our pedagogy, both of which are dishonored daily by current policies. (Strauss, 2014b)

In taking this stand, they are joining collectives of educators at a few schools in Chicago and Seattle, and a number of individual teachers - as well as many parents - who also have chosen to opt out of the tests. They are taking a morally complex position, as there is the risk if test participation drops below 95\% that schools and districts will lose federal funds. But especially if the movement spreads (it's frankly quite nascent at the moment), such risks may lessen. State and federal departments of education may not be inclined to take action against dozens of districts and thousands of teachers. In the meantime, however, they really are taking a highly risky action, leaving themselves open to significant disciplinary penalties and their schools open to various funding losses. The decision about what to accept as given and what to raise one's voice about to protest is thus a morally fraught and ambiguous enterprise.

\section{Leaving It All Behind}

In the face of such "intractable dilemmas" (Santoro \& Morehouse, 2011, p. 2677) some educators respond simply by exiting the system entirely. Doris Santoro and Lisa Morehouse write movingly about "principled leavers" and "conscientious objectors": those who leave teaching because they can no longer stand to collaborate with a system of oppression and injustice. As one teacher put it: 
For a long time, we thought that where we could change [the school system] was in our own classrooms...No matter what came down from above, if we closed our doors and we did what we believed was right, we could go forward. But that turned out not to be the case because what started to come down from above just got worse and worse and worse, and the pressure became so great that there was no way around it. And I think that's the most insidious part of it—the idea that if you haven't prepared your kids for all of this, that you're putting them in a bad place. (Santoro \& Morehouse, 2011, p. 2690) Santoro and Morehouse go on to explain that these teachers are not delicate flowers who "tout inflexible moral yardsticks." Rather, "The principled leavers in this study first compromised the way they believed they should teach in order to negotiate ways to teach well within the system and serve their students. After accommodating their visions of good teaching to remain working with a high-poverty population, they arrived at a juncture at which their work was incompatible with their visions for good teaching, working with students, and their own sense of the good life" (Santoro \& Morehouse, 2011).

Educators do not always exit silently. Some who quit due to moral outrage do so in tandem with exercising their voice, by publishing their resignation letters on-line. Cambridge Public Schools kindergarten teacher Susan Sluyter's 2014 letter of resignation, for example, went viral after being featured in Valerie Strauss' education blog for the Washington Post. Sluyter's letter read in part:

Each year I have had less and less time to teach the children I love in the way I know best - and in the way child development experts recommend. I reached the place last year where I began to feel I was part of a broken system that was causing damage to those very children I was there to serve. I was trying to survive in a community of 
colleagues who were struggling to do the same: to adapt and survive, to continue to hold onto what we could, and to affirm what we believe to be quality teaching for an early childhood classroom. I began to feel a deep sense of loss of integrity. I felt my spirit, my passion as a teacher, slip away. I felt anger rise inside me. I felt I needed to survive by looking elsewhere and leaving the community I love so dearly. I did not feel I was leaving my job. I felt then and feel now that my job left me. (Strauss, 2014a) As with Santoro and Morehouse's "principled leavers," Sluyter describes a similarly agonizing trajectory of accommodation leading to anger leading ultimately to exit when the violation of her personal and professional integrity became too great.

In exiting, these educators preserve — or perhaps reestablish—-their sense of personal integrity, which is clearly a moral good. Bernard Williams emphasizes that "each of us is specially responsible for what he does, rather than for what other people do" (Williams, 1973, p. 99). They also may be helping to protect the integrity of the profession itself, at least when exit is accompanied by voice. Through exiting, they are refusing to be complicit in the perverting the practice of education and the role of educator (see Santoro, 2013 for a careful discussion of this protection of both self and profession). However, especially when exit by one agent simply entails entrance by another-in other words, when the work will continue, but just with someone else in the role — exit risks being self-indulgent. Dennis Thompson offers exactly this rejoinder to Williams: "Acting to protect one's personal integrity, at the expense of avoidable and serious harm to other people, seems too close to moral self-indulgence; it could represent an effort to keep one's hands clean no matter what happens to the rest of society" (Thompson, 1980, p. 910). Lipsky similarly asks, "Should teachers, police officers, or social workers look for other work rather than participate in practices that seem far from ideal? This would mean leaving clients to 
others who have even fewer concerns and less interest in clients than they do" (Lipsky, 2010, p. $\mathrm{xv})$.

This brings us to the classic problem of "dirty hands," which was reintroduced into the contemporary philosophical literature by Michael Walzer (Walzer, 1973). Writing in the aftermath of Watergate (although the aftermath of the 2014 McCutcheon campaign finance decision will likely do just as well), Walzer considers the moral standing of politicians who must corrupt themselves in order to get elected. In particular, he is interested in the case of the politician we want to corrupt himself so that he'll get elected. We want this of this politician precisely because he is so appalled by his own corruption, which he correctly identifies as such. "Because he has scruples...we know him to be a good man. But we... hope that he will overcome his scruples and make the deal. It is important to stress that we don't want just anyone to make the deal; we want him to make it, precisely because he has scruples about it. We know he is doing right when he makes the deal because he knows he is doing wrong" (Walzer, 1973, p. 166). Later, Walzer summarizes his position: "Here is the moral politician: it is by his dirty hands that we know him. If he were a moral man and nothing else, his hands would not be dirty; if he were a politician and nothing else, he would pretend that they were clean" (Walzer, 1973, p. 168).

\section{Education and Moral Injury}

This seems to be the position in which educators who work under conditions of contextual and school-based injustice find themselves. The best ones are repelled by the injustices they enact—but it is precisely because they experience such revulsion that we should want them to remain in the profession. The most ethically conscientious educators, in other words, are those who are most susceptible to the harm of moral injury: as I defined it earlier, the 
trauma of doing significant moral wrong toward others, which inflicts a moral wrong upon themselves. What is true for ethically-conscious educators, of course, is also true for other ethically-conscious street-level bureaucrats — police officers, social workers, and so forth — and in fact for anyone who has a role that gives them life-altering responsibility for others' lives but denies them the power actually to enact justice. I am not claiming that educators are unique in experiencing moral injury. ${ }^{11}$ Moral injury is brought about by being in a position invested with moral responsibility and authority but being unable to satisfy those responsibilities - and in fact, finding oneself perpetrating acts that significantly wrong others. The trauma of perpetrating significant moral wrong against others is a moral injury suffered by the perpetrator herself, distinct from the wrong done to the original victims. ${ }^{12}$

In defining moral injury this way, I'm diverging a bit from the current literature, which is mostly focused on the psychological trauma experienced by the agent. Brett Litz et al. have written the most comprehensive and widely-cited account of moral injury, which they define as "the lasting psychological, biological, spiritual, behavioral, and social impact of perpetrating, failing to prevent, or bearing witness to acts that transgress deeply held moral beliefs and expectations." In essence, they claim the injury is a psychological, biological, and social one

\footnotetext{
${ }^{11}$ There is a burgeoning literature in the nursing field, for example, about the phenomenon of "moral distress," which seems closely related to moral injury.

${ }^{12}$ I think that this concept of moral injury also sheds light on two classic thought experiments in ethics. In the (in)famous "trolley problem," a man sees a runaway trolley careening down a track on which five people are trapped. He can watch the trolley run them over and kill them, or he can pull a switch that will shift the trolley onto an alternate track, where one person is trapped and will therefore be killed. An enormous literature addresses the morality of passively watching five people be killed versus actively causing one person to be killed (including whether this is even the right way to describe the problem). But surprisingly little attention is given to the moral harm that is potentially done to the agent himself by being put in position of having to make such a choice in the first place. Even if (as I believe) it is morally right for the man to pull the switch and cause the death of one person while saving five other lives, the man is still right to feel that he has committed a moral wrong by causing the death of an innocent person. He thereby suffers a moral injury that is distinct from the moral harm perpetrated upon the innocent victim on the track. This also means that he may well deserve compensation if the trolley was out of control because of another's negligence or (worse still) intentional wrongdoing. I believe that similar considerations are warranted in the "Heinz dilemma," about whether a man should steal medicine to save his dying wife (Kohlberg, 1981).
} 
caused by their "exposure to morally questionable or ethically ambiguous situations" (Litz et al., 2009, p. 697). By contrast, former Marine and Iraq War veteran Tyler Boudreau emphasizes the moral nature of the injury itself, which I think is crucially important. "Moral injury is about the damage done to our moral fiber when transgressions occur by our hands, through our orders, or with our connivance. When we accept these transgressions, however pragmatically (for survival, for instance), we sacrifice a piece of our moral integrity. That's what moral injury is all about" (Boudreau, 2011, p. 749). It's not just the agent's psyche that is damaged; it is also his or her moral integrity.

This is itself, therefore, a moral harm. We commit a moral harm, not just a psychological one, when we place agents (like educators) in morally untenable positions, such as those in which enacting justice is impossible. So not only are the agents themselves violating moral strictures, but so are we as a society, by imposing this price on others. Walzer cautions about dirty hands, "A man doesn't lose his soul one day and find it the next” (Walzer, 1973, p. 177). By placing ethically conscientious educators in the positions I've been talking about, we as a polity are morally complicit in forcing men and women into losing some portion of their soulsor at least of their integrity.

Interestingly, I heard exactly these concerns expressed repeatedly in interviews I conducted in 2013 with principals from high-poverty urban high schools. When asked to identify dilemmas of educational justice with which they wrestled, principals talked movingly about their struggles to limit educators' senses of responsibility toward their students, describing this effort as being among the hardest moral challenges they faced in their own jobs. As one principal explained, it's challenging to teach one's staff that "they can feel that setting limits is a positive thing and not an 'I'm turning my back on my kid' kind of thing." Tellingly, she brought 
up this challenge after she herself had spent twenty minutes describing the ways in which she was bending over backwards to keep a few very troubled students in school and help them graduate. Another principal agonized over whether her mostly white and middle-class teachers should respond to their low-income students' personal appeals for help. "There's a part of me that wants to say, 'We can't be responsible for all the injustice in the universe.' But there's another part of me that says, 'We teach our kids to advocate for themselves, we teach them to locate people with social capital. And for many of our kids, the people that they know with social capital are us." Under more just social conditions—-in which children reliably had winter coats during a snowstorm, in which high school graduates weren't forced to decide whether to spend their savings on community college tuition or on diapers and food for their young nephews, in which families growing up in poverty were less physically, socially, and economically isolatededucators wouldn't confront these dilemmas. But under current conditions, they confront such moral conundrums all too often.

Given that these educators' moral suffering is at the hand of the social and political collective, what principles and practices should guide society's obligations toward educators who suffer moral injury? Most ambitiously but also most crucially, society has the responsibility to reduce educators' susceptibility to moral injury by reducing both contextual and school-based injustice. This includes general social and economic reforms such as poverty alleviation and universal health care. It also includes education-specific reforms such as more professional support for teachers and better funding for guidance counselors. As a polity, we delegate to educators the responsibility to enact justice toward students, and to enable students' experience of justice. At the same time, however, we retain the responsibility of ensuring the justice of the educational system as a whole; this is the obligation of the polity, not of the individual educator. 
That being said, such work will need to be undertaken collaboratively with educators and policy makers, as well as with families and students; it cannot be solely outsiders' attempts to diagnose and fix problems that insiders to schools and districts are better positioned to understand. Educators, school and district leaders, and families can give voice to the particular features of classrooms, schools, communities, and children's lives that make it so hard for schools to enact justice - and that in particular, place them in the position of enacting injustice despite their most fervent attempts not to.

Such collaboration may also reduce moral injury in a second way, by enabling experienced educators and administrators to share their own wisdom about how to create procedures, classroom and school cultures, pedagogies, and so forth, that cut through what otherwise appear to be intractable normative challenges. One class of moral injury, for example, comes about because of predictable patterns of competing needs between individual students or groups of students. Such needs can overwhelm the most dedicated educators. But very expert educators also know how to eliminate some (although certainly not all) of this apparent competition for their scarce time and attention through such techniques as Universal Design for Learning (UDL), peer coaching, use of content-rich "leveled texts" with struggling readers, or other approaches. In supporting multiple, diverse learners in these ways, they reduce the number and seriousness of incidents in which students have truly competing needs that must, but cannot, be simultaneously met. ${ }^{13}$

Moral injury might also be mitigated through changes in schoolwide practices. In Jorge's case, it's possible that if St. Francis adopted a restorative justice approach rather than PBIS, administrators would not have had to make inherently unjust choices about students' lives. Jorge

\footnotetext{
${ }^{13}$ In part for this reason, I think that (Jencks, 1988) offers perhaps a useful start for reasoning about teachers' ethical obligations in the classroom, but by no means a useful end.
} 
might have been enabled to take public responsibility for his transgression, taking restorative action that might satisfy the demands of justice without the school's needing to fall back on mercy. ${ }^{14}$ Educators who are attuned to considerations of justice and have a high degree of expertise in their work may therefore help reduce incidences of moral injury by sharing their practical wisdom with others. Just because educators and policy makers find themselves trying to enact justice where no just action is possible in the moment, doesn't mean that no just action could be possible had different procedures or practices been in place. Apparent conflicts can sometimes be resolved.

At the same time, we must acknowledge that fully eliminating moral injury is impossible, and even undesirable. This is because the experience of moral injury often represents moral progress: actions that had been seen as perfectly acceptable in the past now become experienced as moral violations. For example, even as universal elementary and secondary education became the norm in the United States in the 1950s, children with special needs were routinely warehoused in classrooms or institutions that provided little or no educational services—or the children were denied a school place altogether. Such practices were seen as normal and appropriate. Educators and policy makers who collaborated in denying children with special needs access to schools generally did not see themselves as perpetrating injustice. Now, however, not only are most children with special needs learning in mainstreamed classrooms, but many educators do experience moral injury when they find themselves complicit in denying additional services to these children. This represents unequivocal moral progress (even if there is

\footnotetext{
${ }^{14}$ As a 2014 This American Life episode about school discipline made clear, however, school-based restorative justice approaches may be undercut by a criminal justice system that rejects dialogue in favor of criminal charges and retribution (Glass, 2014). Even if St. Francis had had a system in place that enabled Jorge to restore the school to its prior state, his probation officer may well have pulled him out anyway in the light of his having committed a new criminal offense.
} 
still a long way to go on a practical level with respect to meeting all children's educational needs). Similarly, although I argued above that pedagogical, organizational, and cultural reforms in classrooms, schools, and districts can eliminate some injustices, more functional and just systems may often reveal other forms of injustice that were previously obscured. While society should work hand-in-hand with educators and policy makers to reduce unnecessary moral injury, therefore, it should also raise expectations for justice in these reformed contexts-expectations that in turn will actually increase educators' experience of moral injury along other dimensions.

Correlatively, those who prepare and support educators should arguably also be working to increase educators' experience of moral injury. As I've defined it above, moral injury is the trauma of perpetrating significant moral wrong against others, despite one's most fervent wishes not to. The problem is that many educators do not recognize the moral wrong they are enacting, and hence also do not experience the trauma of wronging others. Their actions do inflict moral wrong against others, but because they do not recognize this fact, they also do not feel injured by their actions. To return to the "dirty hands" literature, it's not the case that this educator is the equivalent of "a politician and nothing else," who "pretend[s] that [her hands] were clean." Rather, she wrongly believes her hands actually to be clean. But educators who fail to recognize their obligations to enact justice will likely perpetrate further injustices on those whom they teach and serve. They have no reason to try to surmount, overturn, or bypass injustices that either they do not recognize or they do not see themselves as responsible for combatting. Hence, it is crucial that educators learn to identify these contextual and school-based injustices, and come to recognize their obligation to enact justice in their work, even if these transformations make them newly vulnerable to the experience of moral injury. 
Educators deserve resources to learn how to eliminate moral injury where possible (e.g. by learning techniques from expert educators that eliminate apparently intractable trade-offs and hence actually enable them to meet the demands of justice). They should be supported in their attempts to strive for justice, and enabled as much as possible to achieve it via education-specific and more general social and economic reforms. But since moral injury is to some extent inevitable, at least under the non-ideal conditions that afflict schools and societies worldwide, educators equally deserve resources to learn how to grapple with (even if not fully meet) the demands of enacting justice in ethically complex and challenging circumstances. This is especially true if we want morally responsible educators to stay in the profession and retain their commitment to enacting justice in their work through public rather than subversive means.

Returning full circle to the methods of phronetic, grounded reflective equilibrium, I suggest that on-going conversations about specific cases and dilemmas like Jorge's are likely to help. In my work creating and directing the Justice in Schools project, I have—on occasion individually, but more frequently in collaboration with my students, teachers, school leaders, and parents - researched and written about a dozen normative case studies of dilemmas of justice that arise in schools and school districts. (See http://justiceinschools.org for examples of some of these cases.) I have piloted these cases with groups of educators, policy makers, social scientists, and philosophers ranging in size from 3-250; some middle and high schools have also used the cases themselves in professional development sessions and faculty meetings. I have been struck in every instance by how grateful educators themselves are to have conversations about cases like these. The mere affirmation that they do have ethical responsibilities - even if they have no idea how to satisfy these obligations, and I can't provide them clear answers, either-is in itself remarkably empowering. It's kind of like going to the doctor and being reassured, "Your 
problems are not all in your head. You truly have been hurt." Furthermore, educators and scholars alike seem to experience themselves engaging in real ethical learning when they grapple with cases like these. They work together to identify potential values at stake, wrestle with the case by assuming diverse perspectives, and help one another identify policies and practices that may mitigate or even resolve such dilemmas immediately and/or in the long term—exactly as phronetic reflection should. I believe such mutual engagement also reflects the value of having nuanced, deeply researched, and narratively complex cases to discuss, as opposed to briefer, fictional cases that are designed to acquaint novice educators with some key ethical theories or principles (Infantino \& Wilke, 2009; Shapiro \& Gross, 2013; Strike \& Soltis, 2009; Zubay \& Soltis, 2005). Finally, I also hope that public discussions about real ethical cases will increase our collective understandings of the justices and injustices at play in schools, and how they connect to more general contextual injustices. If we come to understand the challenges and opportunities better, then we may also increase our capacities and will so as to make real change - change that reduces the prevalence of moral injury altogether.

\section{References}

Allen, Danielle S., \& Reich, Rob (Eds.). (2013). Education, Justice, and Democracy. Chicago: Chicago University Press.

Apple, Michael W., \& Beane, James A. (Eds.). (2007). Democratic Schools: Lessons in Powerful Education. Portsmouth, NH: Heinemann.

Aviv, Rachel. (2014). Wrong Answer. The New Yorker, 90(20), 54-65. Boudreau, Tyler. (2011). The Morally Injured. The Massachusetts Review, 52(3-4), 746-754. Brighouse, Harry. (2000). School Choice and Social Justice. Oxford: Oxford University Press. Brighouse, Harry, \& Unterhalter, Elaine. (2010). Education for Primary Goods or For Capabilities? In H. Brighouse \& I. Robeyns (Eds.), Measuring Justice: Primary Goods and Capabilities (pp. 193-214). Cambridge: Cambridge University Press.

Campbell, Elizabeth. (2003). The Ethical Teacher. Maidenhead, UK: Open University Press. Campbell, Elizabeth. (2008). The Ethics of Teaching as a Moral Profession. Curriculum Inquiry, 38(4), 357-385. doi: 10.1111/j.1467-873X.2008.00414.x

Carr, David. (2000). Professionalism and Ethics in Teaching. New York: Routledge. 
Dodson, Lisa. (2011). The Moral Underground: How Ordinary Americans Subvert an Unfair Economy. New York: The New Press.

Flyvbjerg, Bent. (2001). Making Social Science Matter: Why Social Inquiry Fails and How It Can Succeed Again. New York: Cambridge University Press.

Freire, Paulo. (2000 [1970]). Pedagogy of the Oppressed, 30th Anniversary Edition. In T. b. M. B. Ramos (Ed.). New York: Continuum.

Glass, Ira (Writer). (2014). Is This Working?, This American Life. Chicago: WBEZ.

Goodlad, John I., Soder, Soder, \& Sirotnik, Kenneth A. (Eds.). (1990). The Moral Dimensions of Teaching. San Francisco: Jossey-Bass.

Hirschman, Albert O. (1970). Exit, Voice, and Loyalty. Cambridge, MA: Harvard University Press.

Infantino, Robert, \& Wilke, Rebecca. (2009). Tough Choices for Teachers: Ethical Challenges in Today's Schools and Classrooms. New York: Rowman and Littlefield.

Jencks, Christopher. (1988). Whom Must We Treat Equally for Educational Opportunity to be Equal? Ethics, 98(3), 518-533.

Kant, Immanuel. (1999). Critique of Pure Reason (P. Guyer, Trans.). Cambridge: Cambridge University Press.

Kohlberg, Lawrence. (1981). Essays on Moral Development (Vol. I: The Philosophy of Moral Development). San Francisco: Harper and Row.

Levinson, Meira. (2012). No Citizen Left Behind. Cambridge, MA: Harvard University Press.

Levinson, Meira. (2014). It's (Still) All In Our Heads: Non-Ideal Theory as Grounded Reflective Equilibrium. Philosophy of Education Yearbook.

Lipsky, Michael. (2010). Street-Level Bureaucracy: Dilemmas of the Individual in Public Services, 30th Anniversary Expanded Edition. New York: Russell Sage.

Litz, Brett T., Stein, Nathan, Delaney, Eileen, Lebowitz, Leslie, Nash, William P., Silva, Caroline, \& Maguen, Shira. (2009). Moral injury and moral repair in war veterans: A preliminary model and intervention strategy. Clinical Psychology Review, 29(8), 695706. doi: dx.doi.org/10.1016/j.cpr.2009.07.003

Mills, Charles W. (2005). 'Ideal Theory' as Ideology. Hypatia, 20(3), 165-183.

Noddings, Nel. (2013). Caring: A Relational Approach to Ethics and Moral Education, 2013 edition (2nd ed.). Berkeley and Los Angeles, CA: University of California Press.

Nussbaum, Martha. (2000). Women and Human Development: The Capabilities Approach. New York: Cambridge University Press.

Picower, Bree. (2012). Practice What You Teach: Social Justice Education in the Classroom and the Streets. New York: Routledge.

Rawls, John. (1971). A Theory of Justice. Cambridge, MA: Belknap Press of Harvard University Press.

Rawls, John. (1993). Political Liberalism. New York: Columbia University Press.

Reich, Rob. (2002). Bridging Liberalism and Multiculturalism in American Education. Chicago: University of Chicago Press.

Rittel, Horst W. J., \& Webber, Melvin M. (1973). Dilemmas in a General Theory of Planning. Policy Sciences, 4, 155-169.

Sanger, Matthew N., \& Osguthorpe, Richard D. (Eds.). (2013). The Moral Work of Teaching and Teacher Education: Preparing and Supporting Practitioners. New York: Teachers College Press. 
Santoro, Doris A. (2013). 'I Was Becoming Increasingly Uneasy About the Profession and What Was Being Asked of Me': Preserving Integrity in Teaching. Curriculum Inquiry, 43(5), 563-587. doi: 10.1111/curi.12027

Santoro, Doris A. (2014). 'I began to feel a deep sense of loss of integrity:' Teachers' Expressions of Craft Conscience. Unpublished ms, submitted to Harvard Education Review.

Santoro, Doris A., \& Morehouse, Lisa. (2011). Teaching's Conscientious Objectors: Principled Leavers of High-Poverty Schools. Teachers College Record, 113(12), 2670-2704.

Scott, James C. (1985). Weapons of the Weak: Everyday Forms of Peasant Resistance. New Haven: Yale University Press.

Sen, Amartya. (1993). Capability and Well-Being. In M. Nussbaum \& A. Sen (Eds.), The Quality of Life (pp. 30-53). Oxford: Clarendon Press.

Shapiro, Joan Poliner, \& Gross, Steven Jay. (2013). Ethical Educational Leadership in Turbulent Times: (Re)Solving Moral Dilemmas, Second Edition. New York: Routledge.

Strauss, Valerie. (2014a, March 23). Kindergarten Teacher: My Job is Now About Tests and Data — Not Children. I Quit. Retrieved from http://www.washingtonpost.com/blogs/answer-sheet/wp/2014/03/23/kindergartenteacher-my-job-is-now-about-tests-and-data-not-children-i-quit/

Strauss, Valerie. (2014b, April 4, 2014). Teachers Refuse to Administer Standardized Tests. Retrieved from http://www.washingtonpost.com/blogs/answersheet/wp/2014/04/04/teachers-refuse-to-administer-standardized-tests/.

Strike, Kenneth A., \& Soltis, Jonas F. (2009). The Ethics of Teaching, Fifth Edition. New York: Teachers College Press.

Thatcher, David. (2006). The Normative Case Study. American Journal of Sociology, 111(6), 1631-1676.

Thompson, Dennis F. (1980). Moral Responsibility of Public Officials: The Problem of Many Hands. The American Political Science Review, 905-916.

Thomson, Judith Jarvis. (1990). The Realm of Rights. Cambridge, MA: Harvard University Press.

Tom, Alan R. (1984). Teaching as a Moral Craft. New York: Longman.

Walzer, Michael. (1973). Political Action: The Problem of Dirty Hands. Philosophy \& Public Affairs, 2(2), 160-180.

Westheimer, Joel, \& Kahne, Joseph. (2002). Educating for Democracy. In R. Hayduck \& K. Mattson (Eds.), Democracy's Moment: Reforming the American Political System for the 21st Century (pp. 91-107). Boulder: Rowman \& Littlefield.

Williams, Bernard. (1973). A Critique of Utilitarianism. In J. J. C. Smart \& B. Williams (Eds.), Utilitarianism: For and Against (pp. 77-150). Cambridge: Cambridge University Press.

Wolfe, Alan (Ed.). (2003). School Choice: The Moral Debate. Princeton: Princeton University Press.

Zubay, Bongsoon, \& Soltis, Jonas F. (2005). Creating the Ethical School. New York: Teachers College Press. 